\title{
Parameterization of ion-induced nucleation rates based on ambient observations
}

\author{
T. Nieminen ${ }^{1}$, P. Paasonen ${ }^{1}$, H. E. Manninen ${ }^{1}$, K. Sellegri ${ }^{2}$, V.-M. Kerminen ${ }^{1,3}$, and M. Kulmala ${ }^{1,4,5}$ \\ ${ }^{1}$ Department of Physics, P.O. Box 64, 00014 University of Helsinki, Finland \\ ${ }^{2}$ Laboratoire de Météorologie Physique, Blaise Pascal Univ., 63000, Clermont-Ferrand, France \\ ${ }^{3}$ Finnish Meteorological Institute, Research and Development, P.O. Box 503, 00101 Helsinki, Finland \\ ${ }^{4}$ Department of Physics, Lund University, P.O. Box 118, 221 00, Sweden \\ ${ }^{5}$ Department of Applied Environmental Science (ITM) Stockholm University, Svante Arrheniusväg 8, \\ 10691 Stockholm, Sweden
}

Received: 16 June 2010 - Published in Atmos. Chem. Phys. Discuss.: 17 September 2010

Revised: 27 January 2011 - Accepted: 4 February 2011 - Published: 11 April 2011

\begin{abstract}
Atmospheric ions participate in the formation of new atmospheric aerosol particles, yet their exact role in this process has remained unclear. Here we derive a new simple parameterization for ion-induced nucleation or, more precisely, for the formation rate of charged 2-nm particles. The parameterization is semi-empirical in the sense that it is based on comprehensive results of one-year-long atmospheric cluster and particle measurements in the size range $\sim 1-42 \mathrm{~nm}$ within the EUCAARI (European Integrated project on Aerosol Cloud Climate and Air Quality interactions) project. Data from 12 field sites across Europe measured with different types of air ion and cluster mobility spectrometers were used in our analysis, with more in-depth analysis made using data from four stations with concomitant sulphuric acid measurements. The parameterization is given in two slightly different forms: a more accurate one that requires information on sulfuric acid and nucleating organic vapor concentrations, and a simpler one in which this information is replaced with the global radiation intensity. These new parameterizations are applicable to all large-scale atmospheric models containing size-resolved aerosol microphysics, and a scheme to calculate concentrations of sulphuric acid, condensing organic vapours and cluster ions.
\end{abstract}

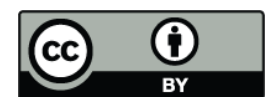

Correspondence to: T. Nieminen (tuomo.nieminen@helsinki.fi)

\section{Introduction}

Formation of new atmospheric aerosol particles by nucleation is a frequent and world-wide phenomenon (Kulmala et al., 2004; Kulmala and Kerminen, 2008). Nucleated particles have been observed to grow into cloud condensation nuclei (CCN) sizes (e.g. Laaksonen et al., 2005; Wiedensohler et al., 2009), and to participate in cloud droplet activation (Kerminen et al., 2005). Model investigations demonstrate that nucleation may contribute significantly to the number concentration of $\mathrm{CCN}$, and thereby to indirect climate forcing, in the global atmosphere (e.g. Spracklen et al., 2008; Merikanto et al., 2009; Pierce and Adams, 2009).

Although our understanding on atmospheric nucleation has increased substantially during last few years (e.g. Kerminen et al., 2010), quantifying the climatic and other effects of atmospheric nucleation is probably not possible without knowing the dominating nucleation pathways in different environments and under varying atmospheric conditions. One important source of uncertainty in this respect is the role of ions: while they are known to influence both nucleation and subsequent growth of nucleated particles (e.g. Nadykto and Yu, 2003; Winkler et al., 2008), the overall effect of ions on atmospheric aerosol formation has remained controversial (Enghoff and Svensmark, 2008; Kazil et al., 2008; Yu et al., 2010; Kulmala et al., 2010; Mirme et al., 2010).

Over the years, a few parameterizations to treat ioninduced nucleation in large-scale atmospheric models have been developed (Turco et al., 1998; Modgil et al., 2005; Kazil and Lovejoy, 2007; Yu, 2008). All these parameterizations reproduce the underlying nucleation theory with good

Published by Copernicus Publications on behalf of the European Geosciences Union. 
accuracy, making them both practical and appealing tools to investigate ion-induced nucleation in the global atmosphere. However, none of these parameterizations have been tested properly against atmospheric measurements due to the general lack of suitable field data for this purpose.

In this work, we develop a new parameterization for ioninduced nucleation, or more precisely for the formation rate of charged 2-nm particles, based entirely on field measurements. The measurement data are obtained from the European Integrated Project on Aerosol Cloud Climate Air Quality Interactions (EUCAARI) project (Kulmala et al., 2009). In EUCAARI, different types of cluster mobility spectrometers were deployed simultaneously in 12 European sites, representing a variety of geographical and atmospheric conditions to quantify the spatial and temporal distribution of the particle formation events (Manninen et al., 2010). The new parameterization is very simple, and it is provided in two different forms to facilitate its use in practically all current atmospheric models capable of simulating aerosol microphysics.

\section{Materials and methods}

\subsection{Measurements}

The Air Ion Spectrometers (AIS), Neutral cluster and Air Ion Spectrometers (NAIS) and Balanced Scanning Mobility Analyzers (BSMA) have been operating simultaneously in 12 field sites in Europe within the EUCAARI project (see map in Fig. 1). The measurements presented in this paper started in March 2008 and ended between February and May 2009 depending on the site (Manninen et al., 2010). The measurements sites were Pallas and Hyytiälä (Finland), Vavihill (Sweden), Mace Head (Ireland), Cabauw (The Netherlands), Melpitz and Hohenpeissenberg (Germany), K-Puszta (Hungary), Jungfraujoch (Switzerland), Puy de Dôme (France), San Pietro Capofiume (Italy) and Finokalia (Greece). These sites represent a wide variety of environments, such as marine, coastal, remote continental, suburban, rural and mountain conditions, as well as altitudes from sea level to several thousand meters above sea level (m a.s.1.).

The more detailed data set used in this study was collected from four of the above mentioned stations: Hyytiälä, Melpitz, Hohenpeissenberg and San Pietro Capofiume (Paasonen et al., 2010). Also these four sites differ significantly in terms of anthropogenic influence, geographical latitude and altitude, ranging from close to sea level in San Pietro Capofiume to $985 \mathrm{~m}$ a.s.l. in Hohenpeissenberg. At these four sites Chemical Ionization Mass Spectrometer (CIMS) was used to measure ambient sulphuric acid concentrations.

The Air Ion Spectrometer (AIS, Mirme et al., 2007) measures mobility distributions of both negative and positive air ions simultaneously in the range between 3.2 and $0.0013 \mathrm{~cm}^{2} \mathrm{~V}^{-1} \mathrm{~s}^{-1}$, which corresponds to a mobility

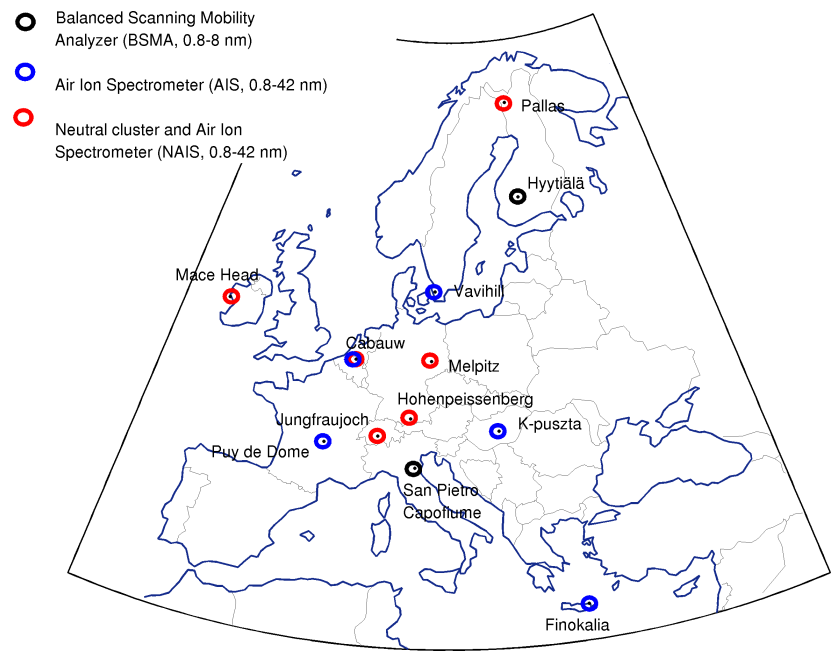

Fig. 1. Locations of the 12 field sites from where data has been used in the parameterizations. The type of ion spectrometer used at each site is indicated by the color of the circle around the station.

diameter range of $0.8-42 \mathrm{~nm}$. We apply here the mobility diameter, i.e. Millikan diameter, when converting the measured mobility to the particle diameter (see Mäkelä et al., 1996). The AIS consists of two parallel cylindrical Differential Mobility Analyzers (DMAs); one DMA classifies negative ions and the other positive ions. The ions are simultaneously classified, according to their electrical mobility, and collected to electrically isolated sections. Each section has its own electrometer to measure the currents carried by the ions. The NAIS (Kulmala et al., 2007) measures in addition the concentration of neutral atmospheric clusters by charging them with a unipolar corona charger prior to analyzing their mobility. In this study, we use only data gathered with the ion mode of the NAISs, and thus it is similar to the AIS data. The Balanced Scanning Mobility Analyzer (BSMA, Tammet, 2006) measures mobility distributions of small air ions and naturally charged aerosol particles of both negative and positive polarity, the mobility distribution is measured by scanning through the corresponding mobility range within $10 \mathrm{~min}$. The mobility range of the BSMA is $3.2-0.032 \mathrm{~cm}^{2} \mathrm{~V}^{-1} \mathrm{~s}^{-1}$, corresponding to the mobility diameter range of $0.8-8.0 \mathrm{~nm}$. The BSMA consists of two plate capacitors, one for each polarity, and a common electrical amplifier connected to a balanced bridge circuit. A more detailed description of the measurements during the EUCAARI and the data set gathered is given in Manninen et al. (2010).

Sulphuric acid concentrations were measured with Chemical Ionization Mass Spectrometers (CIMS). The measurements in Hohenpeissenberg, Melpitz and San Pietro Capofiume were performed with the CIMS operated by the Deutscher Wetterdienst DWD (Berresheim et al., 2000), whereas in Hyytiälä the CIMS of the University of Helsinki was used (Petäjä et al., 2009). These two CIMS instruments 
are built according to the same design, and a similar calibration procedure is used in both of them. However, these two CIMS instruments have not been intercompared. As a result, there could be systematic differences between the sulphuric acid concentrations measured with these different instruments. We do not, however, expect this to result in systematic differences greater than $50 \%$ between the instruments. The measurement uncertainty of the DWD CIMS system has been estimated to be $39 \%$ by Berresheim et al. (2000). The University of Helsinki CIMS measurements have been compared to modelled and proxy sulphuric acid concentrations, and the agreement is good (Petäjä et al., 2009).

We also utilized basic meteorological data, and global radiation data that includes both direct and diffuse solar radiation.

\subsection{Particle formation rates}

The growth rate of the newly formed aerosol population can be determined from the measured number size distributions using the method presented by Hirsikko et al. (2005). A normal distribution function was fitted into the time series of the particle concentrations in every size bin. After determining the moment corresponding to the maximum concentration in each of the size bins, the growth rates (GR) were obtained by a linear least-square fit through the data points in the selected size classes. Negative and positive polarities were analyzed separately. The average charged particle growth rates were obtained for three diameter ranges $(1.5-3 \mathrm{~nm}, 3-7 \mathrm{~nm}$ and $7-20 \mathrm{~nm}$ ) from the AIS data, and in case of BSMA measurements, for the first two size ranges. This was done during the event time, when there was high enough concentrations of ions larger than $2 \mathrm{~nm}$ diameter, so that the growing mode of the newly formed ions could be detected and the growth reliably followed. The growth rate estimated with this method can deviate from the real one by up to a factor two because of observational uncertainties.

The charged particle formation rates were calculated from the ion concentrations measured in the size range of $2-3 \mathrm{~nm}$ by taking into account particle losses due to coagulational scavenging, growth of particles out of the considered size range, and losses due to ion-ion recombination. Sources due to charging of 2-3 nm neutral particles were taken into account (see Kulmala et al., 2007, supporting information) for those sites in which the NAIS was measuring. The formation rate of charged $2 \mathrm{~nm}$ particles, $J_{2}^{ \pm}$, is thereby obtained from the following equation:

$$
\begin{aligned}
J_{2}^{ \pm}= & \frac{\mathrm{d} N_{2-3}^{ \pm}}{\mathrm{d} t}+\mathrm{CoagS}_{2} \times N_{2-3}^{ \pm}+\frac{1}{1 \mathrm{~nm}} \mathrm{GR}_{3} N_{2-3}^{ \pm} \\
& +\alpha N_{2-3}^{ \pm} N_{<3}^{\mp}-\beta N_{2-3} N_{<2}^{ \pm} .
\end{aligned}
$$

Here the superscript \pm refers to positively and negatively charged particles, $N_{2-3}^{ \pm}, N^{ \pm}<2$ and $N^{ \pm}<3$ are the concentrations of ions and charged particles in the size ranges $2-3 \mathrm{~nm}$, below $2 \mathrm{~nm}$ and below $3 \mathrm{~nm}$, respectively, and $\mathrm{GR}_{3}$ is the particle growth rate at $3 \mathrm{~nm}$. Coagulation sink of $2 \mathrm{~nm}$ ions, $\mathrm{CoagS}_{2}$, is calculated according to Kulmala et al. (2001). The ion-ion recombination coefficient, $\alpha$, and the ion-neutral attachment coefficient, $\beta$, are assumed to be equal to $1.6 \times 10^{-6} \mathrm{~cm}^{3} \mathrm{~s}^{-1}$ and $0.01 \times 10^{-6} \mathrm{~cm}^{3} \mathrm{~s}^{-1}$, respectively (e.g. Tammet and Kulmala, 2005). The ion concentrations were obtained from the charged particle number size distributions measured with AIS and BSMA. As explained above, charging of neutral 2-3 nm particles (last term on the right-hand side of Eq. (1)) was taken into account for the NAIS data only. According to a previous study by Manninen et al. (2009), the magnitude of this term is typically below $10 \%$ of the total particle formation rate. Due to uncertainties both in the measurements and data analysis, the formation rate values estimated here could be higher or lower by approximately a factor of two (Manninen et al., 2009).

\section{Parameterizations}

\subsection{Parameterization based on sulphuric acid and nucleating organic vapors}

In order to derive a new semi-empirical parameterization for ion-induced nucleation, we investigated how the formation rate of charged 2-nm particles depends on the concentrations of cluster ions, sulphuric acid and nucleating organic vapors in our measurement sites. While the involvement of cluster ions and sulphuric acid is quite clear based on earlier studies on ion-induced nucleation (e.g. Kazil and Lovejoy, 2007; Yu et al., 2010), we decided to include also organic vapors in the parameterization because of their plausible participation in atmospheric nucleation processes (see e.g. Paasonen et al., 2009; Metzger et al., 2010). We assumed that the formation rate of charged $2 \mathrm{~nm}$ particles has the following functional form:

$J_{2}^{ \pm}=C^{ \pm} \cdot F\left(N_{\text {clust }}^{ \pm},\left[\mathrm{H}_{2} \mathrm{SO}_{4}\right],[\mathrm{Org}]\right)$.

Here $C^{ \pm}$is the empirical fitting parameter determined by a linear least-squares fit to the measurement data, $N_{\text {clust }}^{ \pm}$is the concentration of cluster ions in the diameter range 0.80 $1.25 \mathrm{~nm}$, and $\left[\mathrm{H}_{2} \mathrm{SO}_{4}\right]$ is the sulphuric acid concentration. The quantity [Org] is the growth-equivalent organic vapor concentration, i.e. the concentration needed to explain the observed particle growth rate from 2 to $4 \mathrm{~nm}$ in addition to calculated growth rate related to sulphuric acid condensation. The time dependent concentration of [Org] is derived by scaling the calculated concentration during the growth rate determination (Hirsikko et al., 2005) by global radiation and condensation sink (Kulmala et al., 2001). The calculation of $[\mathrm{Org}]$ is explained in more detail by Paasonen et al. (2010) and will not be repeated here. 
Table 1. Values of the fitting coefficients $C$ and correlation coefficients for the parameterizations of Eqs. (3) and (5). When using the parameterizations, the cluster ion and vapor concentrations are given in units of molecules $\mathrm{cm}^{-3}$, and global radiation in $\mathrm{W} \mathrm{m}{ }^{-2}$.

\begin{tabular}{lcccc}
\hline & \multicolumn{2}{c}{ Fitting parameter $C^{ \pm}$} & \multicolumn{2}{c}{ Correlation coefficient } \\
& $\mathrm{Neg}\left(^{-}\right)$ & $\operatorname{Pos}\left(^{+}\right)$ & Neg & Pos \\
\hline$J_{2}^{ \pm}=C^{ \pm} \cdot N_{\text {clust }}^{ \pm} \cdot\left(\mathrm{H}_{2} \mathrm{SO}_{4}+\mathrm{Org}\right)^{2}$ & $2.0 \times 10^{-19}$ & $1.9 \times 10^{-19}$ & 0.60 & 0.62 \\
$J_{2}^{ \pm}=C^{ \pm} \cdot N_{\text {clust }}^{ \pm} \cdot\left(\mathrm{H}_{2} \mathrm{SO}_{4}\right)^{2}$ & $6.7 \times 10^{-18}$ & $6.5 \times 10^{-18}$ & 0.19 & 0.30 \\
$J_{2}^{ \pm}=C^{ \pm} \cdot N_{\text {clust }}^{ \pm} \cdot \mathrm{GlobRad}^{2}$ & $7.86 \times 10^{-10}$ & $7.95 \times 10^{-10}$ & 0.44 & 0.41 \\
\hline
\end{tabular}

Since atmospheric nucleation rates have consistently been found to be proportional to the power of 1-2 of the precursor vapor concentrations (e.g. Riipinen et al., 2007; Kuang et al., 2008; Paasonen et al., 2010), function $F$ in Eq. (2) was assumed to be a polynomial containing the terms $N_{\text {clust }}$, $\left[\mathrm{H}_{2} \mathrm{SO}_{4}\right]$ and [Org] raised to the power of 0-2 (Paasonen et al., 2010). We chose the upper size limit of the cluster ions in Eq. (2) to be $1.25 \mathrm{~nm}$, since it is seen from the data that during nucleation events the concentration of cluster ions smaller than this limit is typically diminished, whereas the concentration of larger ions is increasing (see also Nieminen et al., 2009). This can be regarded as evidence of cluster ions smaller than about $1.25 \mathrm{~nm}$ participating in the nucleation processes, probably via an activation mechanism (Kulmala et al., 2006).

By fitting Eq. (2) to the data obtained from the four sites with parallel ion and sulphuric acid measurements and varying the function $F$, we ended up with the following equation:

$J_{2}^{ \pm}=C^{ \pm} \times N_{\text {clust }}^{ \pm}\left(\left[\mathrm{H}_{2} \mathrm{SO}_{4}\right]+[\mathrm{Org}]\right)^{2}$.

Considering the individual terms in Eq. (3), they actually represent three different pathways for nucleation: collision between cluster ion and (i) two sulphuric acid molecules, (ii) two condensing organic vapour molecules, or (iii) one molecule of sulphuric acid and condensing organic vapor. Figure 2 shows how the observed and parameterized formation rates of charged 2-nm particles correlate with each other for the whole data set from the four sites. The correlation coefficients were equal to 0.60 and 0.62 for negative and positive ions, respectively. The values determined for the fitting coefficients $C^{ \pm}$of Eq. (3) are given in Table 1. It is notable that by multiplying the vapour concentration term in Eq. (3) by the ion cluster concentration, the correlations were clearly better than if it was ignored. This suggests that the cluster ions are really taking part in the ion-induced nucleation process. We also tested Eq. (3) without the organic concentration, i.e. parameterization based only on the product of cluster ion concentration and sulphuric acid concentration squared. As can be seen from Fig. $2 \mathrm{c}$ and d, this leads to clearly worse results than the parameterization including the organic concentration. The fitting coefficient in this case is also given in Table 1, although we do not recommend using Eq. (3) without the organics concentration.
In addition to the fittings described in Eq. (3), we tested performance of the following fittings into the same data set:

$J_{2}^{ \pm}=C^{ \pm}\left(N_{\text {clust }}^{ \pm}\right)^{\mathrm{p}_{1}}\left[\mathrm{H}_{2} \mathrm{SO}_{4}\right]^{\mathrm{p}_{2}}[\mathrm{Org}]^{\mathrm{p}_{3}}$,

where the exponents $p_{\mathrm{i}}$ can be 0,1 or 2 . All the different combinations of $p_{\mathrm{i}}$ led to weaker correlations than achieved with Eq. (3). Especially, the correlation coefficients resulting from $p_{3}=0$, i.e. the fittings made with sulfuric acid and ion cluster concentrations alone, did not exceed the value of $r=0.38$. By visual inspection of the fittings made without taking $[\mathrm{Org}]$ into account, we can conclude that these parameterizations are even less reliable than the correlation coefficients would suggest. Furthermore, by changing the vapor concentrations to the power of 1 or by raising $N_{\text {clust }}$ to the power of 2 in Eq. (4), the results were worsened.

\subsection{Parameterization based on solar radiation}

Since the concentrations of sulphuric acid and/or organics are not necessarily available in modeling frameworks or when analysing measurement data, we derived an even simpler form of the parameterization that relies on the intensity of global radiation instead of sulphuric acid and growthequivalent organic vapour concentrations. While very rough, this approach can be justified by considering that (i) the production rate of sulphuric acid, and to large extent also of low-volatile organic vapors, are driven by $\mathrm{OH}$ radicals, (ii) the $\mathrm{OH}$ radical concentration usually follows the UV-B light intensity (Rohrer and Berresheim, 2006), and (iii) the UV-B and global radiation intensity tend to correlate strongly with each other. It has been shown that the sulphuric acid concentration can be parameterized quite well with the help of the solar radiation intensity (Petäjä et al., 2009).

Figure 3 shows how the formation rate of charged 2-nm particles depends on the product of cluster ion concentration and global radiation. The data points in the top-left corners of these plots represent cases when a relatively high charged particle formation rate takes place at low global radiation levels, typically below about $50 \mathrm{~W} \mathrm{~m}^{-2}$. These data points correspond to evening and night periods, and are not related to traditional atmospheric new-particle formation and growth events. This type of night-time cluster ion growth events have been reported, for example, by Junninen et al. (2008) in 

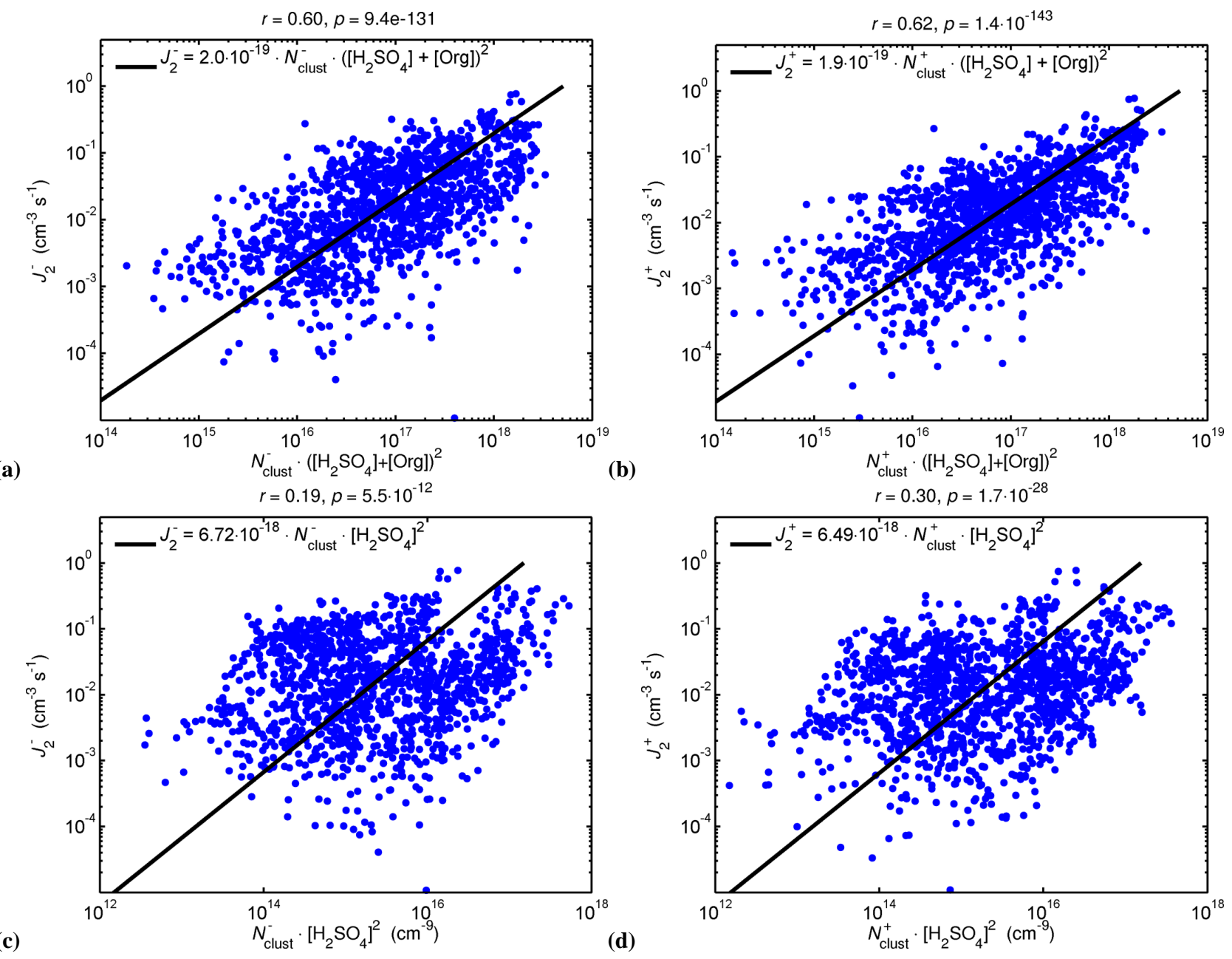

Fig. 2. Ion-induced nucleation rates of (a) negative and (b) positive ions at $2 \mathrm{~nm}$, as a function of cluster ion concentration multiplied with the squared sum of sulphuric acid and growth equivalent organic vapour concentrations. The data is measured in Hyytiälä (May 2007), Hohenpeissenberg (from July 2007 to July 2008), Melpitz (May 2008) and San Pietro Capofiume (July 2009). Panels (c) and (d) show the same $J_{2}$ values when leaving out the organic concentration from the parameterizations. Correlation coefficients and corresponding $p$-values between observed and parameterized values are shown on top of each panel.

measurements conducted at Hyytiälä. If the data points corresponding to these evening and night-time ion events are excluded, the correlation between the observed formation rate of charged 2-nm particles and the product of cluster ion concentration and global radiation becomes much clearer.

We considered the following types of fittings as candidates for the parameterization based on global radiation:

$J_{2}^{ \pm}=C_{\text {rad }}^{ \pm} \cdot\left(N_{\text {clust }}^{ \pm}\right)^{\mathrm{m}} \cdot \mathrm{GlobRad}^{\mathrm{n}}$.

As in the case of Eqs. (2) and (3), $C_{\text {rad }}^{ \pm}$is a semi-empirical fitting parameter determined by a linear least-squares fit between the observed and parameterized formation rate of charged 2-nm particles. GlobRad (in $\mathrm{W} \mathrm{m}^{-2}$ ) is the intensity of global radiation, and the exponents $m$ and $n$ are constrained to values of 1 or 2 . For both negative and positive ions, the best correlation between the observed and parameterized formation rate was obtained with $m=1$ and $n=2$, the correlation coefficients being equal to 0.44 and 0.41 , respectively. The values of the corresponding fitting coefficients $C_{\text {rad }}^{ \pm}$are given in Table 1. Figure 4 shows the relation between the measured and parameterized values of $J_{2}^{ \pm}$for all 12 EUCAARI measurement sites. As one might expect, the parameterization utilizing global radiation is not as good as the one based on the concentrations of sulphuric acid and nucleating organic vapors.

When examining the sites individually, there was roughly an order of magnitude variation in the values of the fitting coefficients $C_{\mathrm{rad}}^{ \pm}$. The smallest values were obtained for Puy de Dome, $1.9 \times 10^{-10}$ for negative and $1.6 \times 10^{-10}$ for positive ions. The highest value for negative ions was was found 

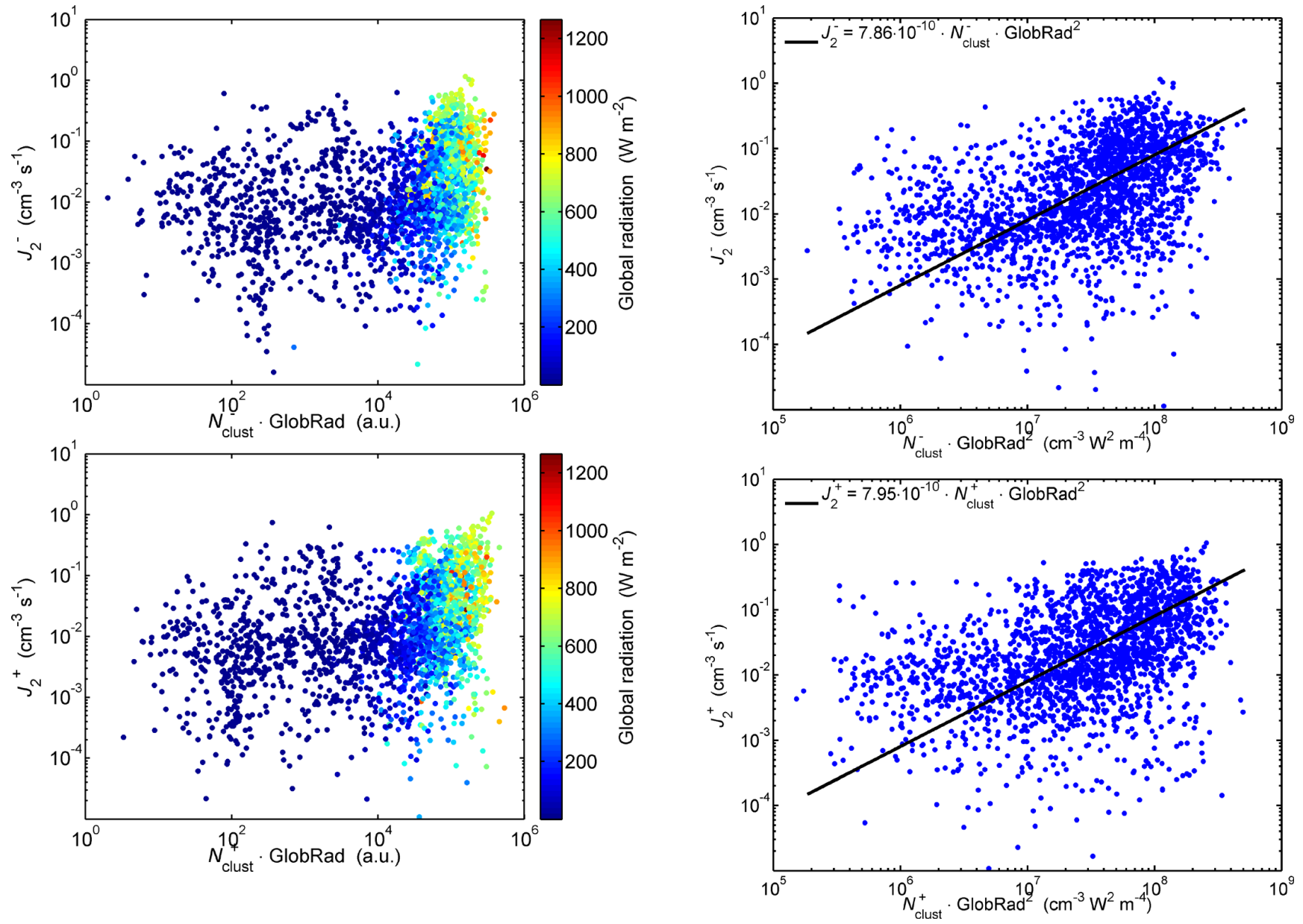

Fig. 3. Ion-induced nucleation rate of (a) negative and (b) positive ions at $2 \mathrm{~nm}$ as a function of the product of cluster ion concentration and global radiation. The data includes all the 12 EUCAARI measurement sites during the 2008-2009 measurement campaign. The color of the data points indicates the intensity of global radiation.

in Hyytiälä $\left(1.9 \times 10^{-9}\right)$, and for positive ions in Cabauw $\left(2.7 \times 10^{-9}\right)$. The correlation coefficients between the observed and parameterized values of $J_{2}^{ \pm}$varied from 0.3 in Hyytiälä and Pallas to roughly 0.6 in Hohenpeissenberg and Melpitz.

Finally, we tested the parameterization based on global radiation Eq. (5) for the data sets obtained at the four stations Hyytiälä, Melpitz, Hohenpeissenberg and San Pietro Capofiume, from which sulphuric acid data were available. Figure 5 shows the comparison between parameterizations given by Eqs. (3) and (5) for this data set. It can be seen that for both negative and positive ions, the parameterization based on the vapor concentrations tends to predict somewhat higher values of $J_{2}$ than the parameterization based on global radiation at times when the observed values of $J_{2}$ were highest. As global radiation is also highest at these times, this might be due to the strong dependence of particularly organic vapor concentrations on other factors than solar radiation. How-

Fig. 4. Formation rates of (a) negative and (b) positive $2 \mathrm{~nm}$ ions as a function of product of cluster ion concentration and square of global radiation. The blue points mark data from the 12 EUCAARI sites data sets, and the black lines are linear least-squares fits to these data points. The data includes all times when global radiation intensity is above $50 \mathrm{~W} \mathrm{~m}^{-2}$. Correlation coefficients between the observed and parameterized formation rates are $r=0.44$ and 0.41 for negative and positive ions, respectively.

ever, no clear correlation between the fitting coefficients $C$ and temperature was found.

\subsection{Determining the cluster ion concentration}

Very few atmospheric models trace the cluster ion concentrations needed to apply (Eqs. 3 and 5). The balance equation for the cluster ion concentration may be written as (see e.g. Laakso et al., 2004):

$\frac{\mathrm{d} N^{ \pm}}{\mathrm{d} t}=Q-\mathrm{CoagS}_{\text {ion }} \cdot N^{ \pm}-\alpha \cdot N^{-} N^{+}$.

The first term on the right hand side of Eq. (6) is the ion production rate, the second term represents the scavenging of 

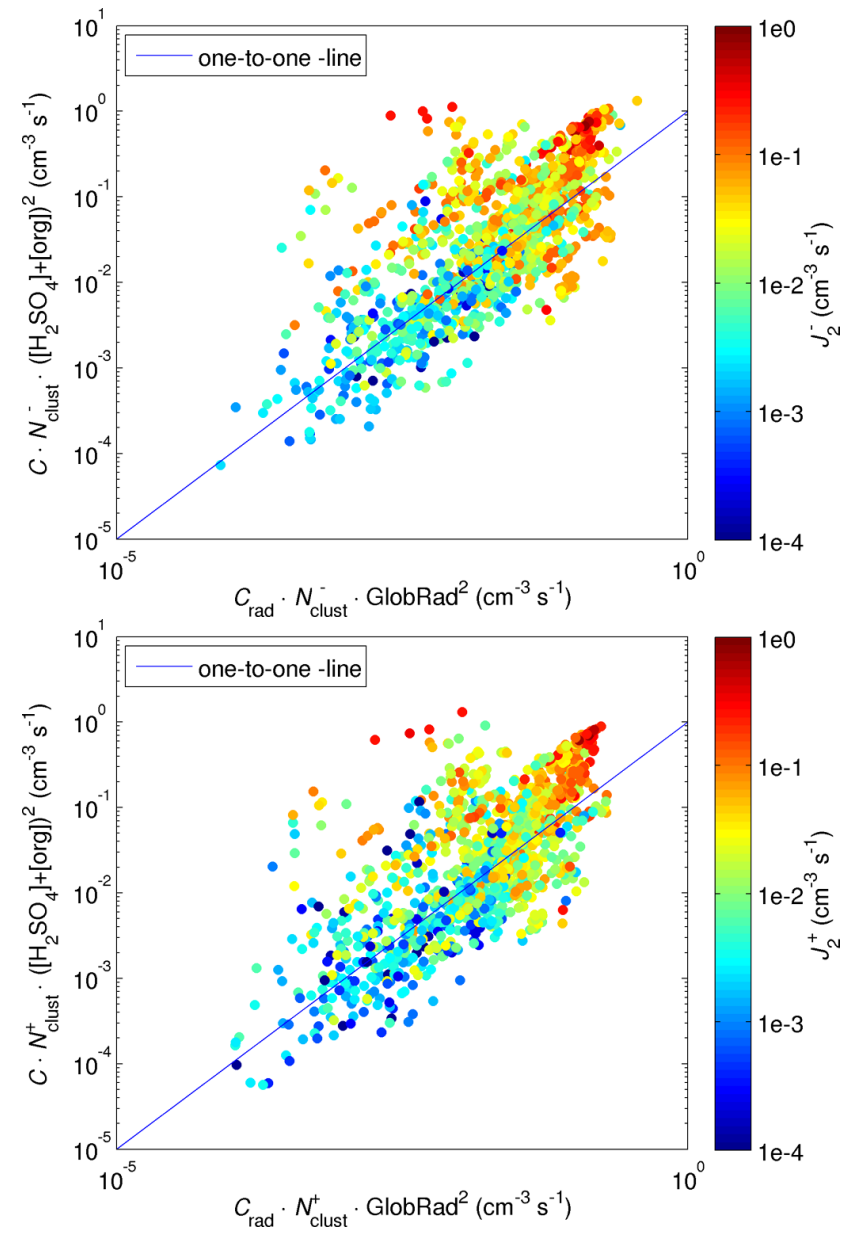

Fig. 5. Comparison of the ion-induced nucleation rate parameterizations of Eqs. (3) and (6) for (a) negative and (b) positive ions based on the data set from Hohenpeissenberg, Melpitz and San Pietro Capofiume. The color of the data points indicates the observed $J_{2}$ value. The values for the fitting coefficients $C$ are those given in Table 1 .

cluster ions with larger pre-existing particles by coagulation, and the third term accounts for the ion-ion recombination. By assuming a pseudo-steady state, i.e. $\mathrm{d} N^{ \pm} / \mathrm{d} t=0$, and that the concentrations of negative and positive cluster ions are equal to each other, i.e. $N^{-}=N^{+} \equiv N^{ \pm}$, Eq. (6) can be solved analytically in two equivalent forms:

$$
\begin{aligned}
& N^{ \pm}=\frac{\sqrt{\operatorname{CoagS}_{\text {ion }}^{2}+4 \cdot \alpha \cdot Q}-\operatorname{CoagS}_{\text {ion }}}{2 \alpha} \\
& =\frac{2 Q}{\operatorname{CoagS}_{\text {ion }}+\sqrt{\operatorname{CoagS}_{\text {ion }}^{2}+4 \cdot \alpha \cdot Q}} .
\end{aligned}
$$

Here, the ion-ion recombination coefficient $\alpha$ is again about $1.6 \times 10^{-6} \mathrm{~cm}^{3} \mathrm{~s}^{-1}$ (Tammet and Kulmala, 2005), and the coagulation sink for cluster ions, $\mathrm{CoagS}_{\text {ion }}$, can be calculated from the pre-existing particle number size distribution according to Kulmala et al. (2001) by approximating that the diameter of cluster ions is about $1 \mathrm{~nm}$. The ion production rate, $Q$ (ion-pairs $\mathrm{cm}^{-3} \mathrm{~s}^{-1}$ ) depends on the flux of cosmic rays and, close to the Earth's surface, also on the natural radioactivity related to radon emissions and direct gamma radiation from the soil (Harrison and Carslaw, 2003). The contribution of cosmic rays to $Q$ can be evaluated quite accurately with help of available models (see Bazilevskaya et al., 2008, and references therein).

\section{Discussion and conclusions}

The main purpose of this paper was to derive a simple, semiempirical parameterization for ion-induced nucleation to be used in large-scale modeling frameworks. We found that the parameterization having the best predictive power requires knowing the concentrations of cluster ions, sulphuric acid and nucleating organic vapors (see also Paasonen et al., 2010). Since both sulphuric acid and nucleating organic vapor concentrations are not available in most current atmospheric models, we derived an additional and even simpler parameterization based on the global radiation intensity and cluster ion concentration. It should be noted that the parameterizations relying on global radiation result in indubitably better approximation for ion induced nucleation rate than those, in which sulphuric acid was considered but the organic vapor concentration was not. Finally, a means to calculate the cluster ion concentration, a quantity not usually traced in large-scale atmospheric models, was provided.

Compared with existing ion-induced nucleation parameterizations (Mogdil et al., 2005; Kazil and Lovejoy, 2007; Yu et al., 2010), the two parameterizations derived here have both their strengths and weaknesses. Clear strengths in this respect are (i) the simplicity of the new parameterizations, (ii) their applicability to practically all atmospheric models containing size-resolved aerosol microphysics, (iii) the practicality of getting the charged particle formation rate at a fixed particle diameter of $2 \mathrm{~nm}$, and (iv) the fact that the new parameterizations rely on field observations at multiple sites, not only on highly uncertain nucleation theories. The apparent drawback in our empirical approach is that it lacks plenty of the physics involved in the ion-induced nucleation process. As a result, our parameterizations cannot capture the influence of temperature and humidity in the nucleation process (Yu et al., 2010), nor the role played by ions of different chemical composition. The data set used to derive the new parameterizations did not include observations from marine areas or upper troposphere, so the performance of the parameterizations in these regions is unclear at the moment.

Large-scale atmospheric models provide, at the end, the only tool to address the role of ion-induced nucleation in the global aerosol production. With this in mind, it would be extremely important to investigate how the different 
ion-induced nucleation parameterizations compare with each other in the global atmosphere, and how they perform in the growing list of field sites with direct measurement data on charged particle formation rates (e.g. Manninen et al., 2010). New measurement data on the formation rates of charged and neutral particles in the middle and upper troposphere over both continental region and marine atmosphere would be extremely useful in this regard.

Acknowledgements. We thank all the researchers, technical staff and students who took part in the field measurements within the EUCAARI project. This work has been supported by European Commission 6th Framework program projects: EUCAARI, contract no. 036833-2 (EUCAARI) and EUSAAR, contract no. 026140 (EUSAAR). The support by the Academy of Finland Centre of Excellence program (project nos. 211483, 211484 and 1118615) is also gratefully acknowledged. EPA Ireland is acknowledged for research support at Mace Head. Support from CNRS-INSU under LEFE-CHAT program for performing AIS measurements at Puy de Dôme is greatly acknowledged. We thank the International Foundation High Altitude Research Stations Jungfraujoch and Gornergrat (HFSJG) for the opportunity to perform experiments at the Jungfraujoch, and MeteoSwiss for providing meteorological data from the Jungfraujoch station.

Edited by: K. Carslaw

\section{References}

Bazilevskaya, G. A., Usoskin, I. G., Flückiger, E. O., Harrison, R. G., Desorgher, L., Bütikofler R., Krainew, M. B., Makhmutov, V. S., Stozhkov, Y. I., Sviirzhevskaya, A. K., Svirzhevsky, N. S., and Kovaltsov, G. A.: Cosmic ray induced ion production in the atmosphere, Space Sci. Rev., 137, 149-173, 2008.

Berresheim, H., Elste, T., Plass-Dülmer, C., Eisele, F. L., and Tanner, D. J.: Chemical ionization mass spectrometer for longterm measurements of atmospheric $\mathrm{OH}$ and $\mathrm{H}_{2} \mathrm{SO}_{4}$, Int. J. Mass. Spectrom., 202, 91-109, 2000.

Enghoff, M. B. and Svensmark, H.: The role of atmospheric ions in aerosol nucleation - a review, Atmos. Chem. Phys., 8, 49114923, doi:10.5194/acp-8-4911-2008, 2008.

Harrison, R. G. and Carslaw, K. S.: Ion-aerosol-cloud processes in the lower atmosphere, Rev. Geophys., 41, 3, 1012, doi:10.1029/2002RG000114, 2003.

Hirsikko, A., Laakso, L., Hörrak, U., Aalto, P. P., Kerminen, V.M., and Kulmala, M.: Annual and size dependent variation of growth rates and ion concentrations in boreal forest, Boreal Environ. Res., 10, 357-369, 2005.

Junninen, H., Hulkkonen, M., Riipinen, I., Nieminen, T., Hirsikko, A, Suni, T., Boy, M., Lee, S.-H., Vana, M., Tammet, H., Kerminen, V.-M., and Kulmala, M.: Observations on nocturnal growth of atmospheric clusters, Tellus B, 60, 365-371, 2008.

Kazil, J. and Lovejoy, E. R.: A semi-analytical method for calculating rates of new sulfate aerosol formation from the gas phase, At- mos. Chem. Phys., 7, 3447-3459, doi:10.5194/acp-7-3447-2007, 2007.

Kazil, J., Harrison, R. G., and Lovejoy, E. R.: Tropospheric new particle formation and the role of ions, Space Sci. Rev., 137, 241255, 2008.

Kerminen, V.-M., Lihavainen, H., Komppula, M., Viisanen, Y., and Kulmala, M.: Direct observational evidence linking atmospheric aerosol formation and cloud droplet activation, Geophys. Res. Lett., 32, L14803, doi:10.1029/2005GL023130, 2005.

Kerminen, V.-M., Petäjä, T., Manninen, H. E., Paasonen, P., Nieminen, T., Sipilä, M., Junninen, H., Ehn, M., Gagné, S., Laakso, L., Riipinen, I., Vehkamäki, H., Kurten, T., Ortega, I. K., Dal Maso, M., Brus, D., Hyvärinen, A., Lihavainen, H., Leppä, J., Lehtinen, K. E. J., Mirme, A., Mirme, S., Hõrrak, U., Berndt, T., Stratmann, F., Birmili, W., Wiedensohler, A., Metzger, A., Dommen, J., Baltensperger, U., Kiendler-Scharr, A., Mentel, T. F., Wildt, J., Winkler, P. M., Wagner, P. E., Petzold, A., Minikin, A., Plass-Dülmer, C., Pöschl, U., Laaksonen, A., and Kulmala, M.: Atmospheric nucleation: highlights of the EUCAARI project and future directions, Atmos. Chem. Phys., 10, 10829-10848, doi:10.5194/acp-10-10829-2010, 2010.

Kuang, C., McMurry, P. H., McCormick, A. V., and Eisele, F. L.: Dependence of nucleation rates on sulfuric acid vapor concentration in diverse atmospheric locations, J. Geophys. Res., 113, D10209, doi:10.1029/2007JD009253, 2008.

Kulmala, M. and Kerminen, V.-M.: On the growth of atmospheric nanoparticles, Atmos. Res., 90, 132-150, 2008.

Kulmala, M., Dal Maso, M., Mäkelä, J. M., Pirjola, L., Väkevä, M., Aalto, P. P., Miikkulainen, P., Hämeri, K., and O’Dowd, C. D.: On the formation, growth and composition of nucleation mode particles, Tellus, 53B, 479-490, 2001.

Kulmala, M., Vehkamäki, H., Petäjä, T., Dal Maso, M., Lauri, A., Kerminen, V.-M., Birmili, W., and McMurry, P. H.: Formation and growth rates of ultrafine atmospheric particles: a review of observations, J. Aerosol Sci., 35, 143-176, 2004.

Kulmala, M., Lehtinen, K. E. J., and Laaksonen, A.: Cluster activation theory as an explanation of the linear dependence between formation rate of $3 \mathrm{~nm}$ particles and sulphuric acid concentration, Atmos. Chem. Phys., 6, 787-793, doi:10.5194/acp-6-787-2006, 2006.

Kulmala, M., Riipinen, I., Sipilä, M., Manninen, H. E., Petäjä, T., Junninen, H., Dal Maso, M., Mordas, G., Mirme, A., Vana, M., Hirsikko, A., Laakso, L., Harrison, R. M., Hanson, I., Leung, C., Lehtinen, K. E. J., and Kerminen, V.-M.: Towards direct measurements of atmospheric nucleation, Science, 318, 89-92, 2007.

Kulmala, M., Asmi, A., Lappalainen, H. K., Carslaw, K. S., Pöschl, U., Baltensperger, U., Hov, Ø., Brenquier, J.-L., Pandis, S. N., Facchini, M. C., Hansson, H.-C., Wiedensohler, A., and O'Dowd, C. D.: Introduction: European Integrated Project on Aerosol Cloud Climate and Air Quality interactions (EUCAARI) - integrating aerosol research from nano to global scales, Atmos. Chem. Phys., 9, 2825-2841, doi:10.5194/acp-9-2825-2009, 2009.

Kulmala, M., Riipinen, I., Nieminen, T., Hulkkonen, M., Sogacheva, L., Manninen, H. E., Paasonen, P., Petäjä, T., Dal Maso, M., Aalto, P. P., Viljanen, A., Usoskin, I., Vainio, R., Mirme, S., Mirme, A., Minikin, A., Petzold, A., Hõrrak, U., Plaß-Dülmer, C., Birmili, W., and Kerminen, V.-M.: Atmospheric data over a solar cycle: no connection between galactic cosmic rays and 
new particle formation, Atmos. Chem. Phys., 10, 1885-1898, doi:10.5194/acp-10-1885-2010, 2010.

Laakso, L., Petäjä, T., Lehtinen, K. E. J., Kulmala, M., Paatero, J., Hõrrak, U., Tammet, H., and Joutsensaari, J.: Ion production rate in a boreal forest based on ion, particle and radiation measurements, Atmos. Chem. Phys., 4, 1933-1943, doi:10.5194/acp-41933-2004, 2004.

Laaksonen, A., Hamed, A., Joutsensaari, J., Hiltunen, L., Cavalli, F., Junkermann, W., Asmi, A., Fuzzi, S., and Facchini, M. C.: Cloud condensation nucleus production from nucleation events at a highly polluted region, Geophys. Res. Lett., 32, L06812, doi:10.1029/2004GL022092, 2005.

Manninen, H. E., Nieminen, T., Riipinen, I., Yli-Juuti, T., Gagné, S., Asmi, E., Aalto, P. P., Petäjä, T., Kerminen, V.-M., and Kulmala, M.: Charged and total particle formation and growth rates during EUCAARI 2007 campaign in Hyytiälä, Atmos. Chem. Phys., 9, 4077-4089, doi:10.5194/acp-9-4077-2009, 2009.

Manninen, H. E., Nieminen, T., Asmi, E., Gagné, S., Häkkinen, S., Lehtipalo, K., Aalto, P., Vana, M., Mirme, A., Mirme, S., Hõrrak, U., Plass-Dülmer, C., Stange, G., Kiss, G., Hoffer, A., Törő, N., Moerman, M., Henzing, B., de Leeuw, G., Brinkenberg, M., Kouvarakis, G. N., Bougiatioti, A., Mihalopoulos, N., O’Dowd, C., Ceburnis, D., Arneth, A., Svenningsson, B., Swietlicki, E., Tarozzi, L., Decesari, S., Facchini, M. C., Birmili, W., Sonntag, A., Wiedensohler, A., Boulon, J., Sellegri, K., Laj, P., Gysel, M., Bukowiecki, N., Weingartner, E., Wehrle, G., Laaksonen, A., Hamed, A., Joutsensaari, J., Petäjä, T., Kerminen, V.-M., and Kulmala, M.: EUCAARI ion spectrometer measurements at 12 European sites - analysis of new particle formation events, Atmos. Chem. Phys., 10, 7907-7927, doi:10.5194/acp-10-79072010, 2010.

Merikanto, J., Spracklen, D. V., Mann, G. W., Pickering, S. J., and Carslaw, K. S.: Impact of nucleation on global CCN, Atmos. Chem. Phys., 9, 8601-8616, doi:10.5194/acp-9-8601-2009, 2009.

Metzger, A., Verheggen, B., Dommen, J., Duplissy, J., Prevot, A. S., Weingartner, E., Riipinen, I., Kulmala, M., Spracklen, D. V., Carslaw, K. S., and Baltensperger, U.: Evidence for the role of organics in aerosol particle formation under atmospheric conditions, Proc. Nat. Acad. Sci., 107, doi:10.1073/pnas.0911330107.

Mirme, A., Tamm, E., Mordas, G., Vana, M., Uin, J., Mirme, S., Bernotas, T., Laakso, L., Hirsikko, A., and Kulmala, M. A.: Wide-range multi-channel Air Ion Spectrometer, Boreal Environ. Res., 12, 247-264, 2007.

Mirme, S., Mirme, A., Minikin, A., Petzold, A., Hõrrak, U., Kerminen, V.-M., and Kulmala, M.: Atmospheric sub-3 nm particles at high altitudes, Atmos. Chem. Phys., 10, 437-451, doi:10.5194/acp-10-437-2010, 2010.

Modgil, M. S., Kumar, S., Tripathi, S. N., and Lovejoy, E. R.: A parameterization of ion-induced nucleation of ic acid and water for atmospheric conditions, J. Geophys. Res., 110, D19205, doi:10.1029/2004JD005475, 2005.

Mäkelä, J. M., Riihelä, M., Ukkonen, A., Jokinen, V., and Keskinen, J.: Comparison of mobility equivalent diameter with KelvinThomson diameter using ion mobility data, J. Chem. Phys., 105, 1562-1571, 1996.

Nadykto, A. B. and Yu, F.: Uptake of neutral polar vapor molecules by charged clusters/particles: Enhancement due to dipole-charge interaction, J. Geophys. Res., 108, 4717,
doi:10.1029/2003JD003664, 2003.

Nieminen, T., Manninen, H. E., Sihto, S.-L., Yli-Juuti, T., Mauldin, R. L., Petäjä, T., Riipinen, I., Kerminen, V.-M., and Kulmala, M.: Connection of sulfuric acid to atmospheric nucleation in boreal forest, Environ. Sci. Technol., 43, 4715-4721, 2009.

Paasonen, P., Sihto, S.-L., Nieminen, T., Vuollekoski, H., Riipinen, I., Plass-Dülmer, C., Berresheim, H., Birmili, W., and Kulmala, M.: Connection between new particle formation and sulfuric acid at Hohenpeissenberg (Germany) including the influence of organic compounds, Boreal Environ. Res., 14, 616-629, 2009.

Paasonen, P., Nieminen, T., Asmi, E., Manninen, H. E., Petäjä, T., Plass-Dülmer, C., Flentje, H., Birmili, W., Wiedensohler, A., Hõrrak, U., Metzger, A., Hamed, A., Laaksonen, A., Facchini, M. C., Kerminen, V.-M., and Kulmala, M.: On the roles of sulphuric acid and low-volatility organic vapours in the initial steps of atmospheric new particle formation, Atmos. Chem. Phys., 10, 11223-11242, doi:10.5194/acp-10-11223-2010, 2010.

Petäjä, T., Mauldin, III, R. L., Kosciuch, E., McGrath, J., Nieminen, T., Paasonen, P., Boy, M., Adamov, A., Kotiaho, T., and Kulmala, M.: Sulfuric acid and $\mathrm{OH}$ concentrations in a boreal forest site, Atmos. Chem. Phys., 9, 7435-7448, doi:10.5194/acp9-7435-2009, 2009.

Pierce, J. R. and Adams, P. J.: Uncertainty in global CCN concentrations from uncertain aerosol nucleation and primary emission rates, Atmos. Chem. Phys., 9, 1339-1356, doi:10.5194/acp-91339-2009, 2009.

Riipinen, I., Sihto, S.-L., Kulmala, M., Arnold, F., Dal Maso, M., Birmili, W., Saarnio, K., Teinilä, K., Kerminen, V.-M., Laaksonen, A., and Lehtinen, K. E. J.: Connections between atmospheric sulphuric acid and new particle formation during QUEST III-IV campaigns in Heidelberg and Hyytiälä, Atmos. Chem. Phys., 7, 1899-1914, doi:10.5194/acp-7-1899-2007, 2007.

Rohrer, F. and Berresheim, H.: Strong correlation between levels fo tropospheric hydroxyl radicals and solar ultraviolet radiation, Nature, 442, 184-187, 2006.

Spracklen, D. V., Carslaw, K. S., Kulmala, M., Kerminen, V.-M., Sihto, S.-L., Riipinen, I., Merikanto, J., Mann, G. W., Chipperfield, M. P., Wiedensohler, A., Birmili, W., and Lihavainen, H.: Contribution of particle formation to global cloud condensation nuclei concentrations, Geophys. Res. Lett., 35, L06808, doi:10.1029/2007GL033038, 2008.

Tammet, H.: Continuous scanning of the mobility and size distribution of charged clusters and nanometer particles in atmospheric air and the Balanced Scanning Mobility Analyzer BSMA, Atmos. Res., 82, 523-535, 2006.

Tammet, H. and Kulmala, M.: Simulation tool for atmospheric aerosol nucleation bursts, J. Aerosol Sci., 36, 173-196, 2005.

Turco, R. P., Zhoo, J.-X., and Yu, F.: A new source of tropospheric aerosols: Ion-ion recombination, Geophys. Res. Lett., 25, 635638, 1998.

Wiedensohler, A., Chen, Y. F., Nowak, A., Wehner, B., Achtert, P., Berghof, M., Birmili, W., Wu, Z. J., Hu, M., Zhu, T., Takegawa, N., Kita, K., Kondo, Y., Lou, S. R., Hofzumahaus, A., Holland, F., Wahner, A., Gunthe, S. S., Rose, D., Su, H., and Pöschl, U.: Rapid aerosol particle growth and increase of cloud condensation nucleaus activity by secondary aerosol formation and condensation: a case study for regional air pollution in northeastern China, J. Geophys. Res., 114, D00G08, doi:10.1029/2008JD010884, 2009. 
Winkler, P. M., Steiner, G., Vrtala, A., Vehkamäki, H., Noppel, M., Lehtinen, K. E. J., Reischl, G. P., Wagner, P. E., and Kulmala, M.: Heterogeneous nucleation experiments bridging the scale from molecular ion clusters to nanoparticles, Science, 319, 1374-1377, doi:10.1126/science.1149034, 2008.

Yu, F., Wang, Z., Luo, G., and Turco, R.: Ion-mediated nucleation as an important global source of tropospheric aerosols, Atmos. Chem. Phys., 8, 2537-2554, doi:10.5194/acp-8-2537-2008, 2008.
Yu, F., Luo, G., Bates, T. S., Anderson, B., Clarke, A., Kapustin, V., Yantosca, R. M., Wang, Y., and Wu, S.: Spatial distributions of particle number concentrations in the global troposphere: Simulations, observations, and implications for nucleation mechanisms, J. Geophys. Res., 115, D17205, doi:10.1029/2009JD013473, 2010. 